\title{
Hydrogen Sulfide: Novel Endogenous and Exogenous Modulator of Oxidative Stress in Retinal Degeneration Diseases
}

\author{
Panpan Li ${ }^{\dagger}$, Hanhan Liu, Xin Shi ${ }^{\dagger}$ and Verena Prokosch* \\ Department of Ophthalmology, Faculty of Medicine and University Hospital Cologne, University of Cologne, \\ 50937 Cologne, Germany; panpanlimed@gmail.com (P.L.); hanhan.liu@uk-koeln.de (H.L.); \\ shixinsx123@gmail.com (X.S.) \\ * Correspondence: verena.prokosch-willing@uk-koeln.de; Tel.: +49-(0)-6131-173326 \\ t These authors contributed equally to this work.
}

check for

updates

Citation: Li, P.; Liu, H.; Shi, X.; Prokosch, V. Hydrogen Sulfide: Novel Endogenous and Exogenous Modulator of Oxidative Stress in Retinal Degeneration Diseases. Molecules 2021, 26, 2411. https:// doi.org/10.3390/molecules26092411

Academic Editors: Luciano Saso, Grzegorz Wegrzyn and Jelena Kotur-Stevuljević

Received: 16 February 2021

Accepted: 19 April 2021

Published: 21 April 2021

Publisher's Note: MDPI stays neutral with regard to jurisdictional claims in published maps and institutional affiliations.

Copyright: (C) 2021 by the authors. Licensee MDPI, Basel, Switzerland. This article is an open access article distributed under the terms and conditions of the Creative Commons Attribution (CC BY) license (https:/ / creativecommons.org/licenses/by/ $4.0 /)$.

\begin{abstract}
Oxidative stress (OS) damage can cause significant injury to cells, which is related to the occurrence and development of many diseases. This pathological process is considered to be the first step to trigger the death of outer retinal neurons, which is related to the pathology of retinal degenerative diseases. Hydrogen sulfide $\left(\mathrm{H}_{2} \mathrm{~S}\right)$ has recently received widespread attention as a physiological signal molecule and gas neuromodulator and plays an important role in regulating OS in eyes. In this article, we reviewed the OS responses and regulatory mechanisms of $\mathrm{H}_{2} \mathrm{~S}$ and its donors as endogenous and exogenous regulators in retinal degenerative diseases. Understanding the relevant mechanisms will help to identify the therapeutic potential of $\mathrm{H}_{2} \mathrm{~S}$ in retinal degenerative diseases.
\end{abstract}

Keywords: oxidative stress; hydrogen sulfide; retinal degeneration diseases; endogenous; exogenous

\section{Introduction \\ 1.1. Oxidative Stress in Human and Diseases}

“They can't survive without oxygen, but at the same time, oxygen will endanger their health", which is an interesting paradoxical connection between aerobic organisms and oxygen [1]. Almost all eukaryotic cells produce reactive oxygen species (ROS) and reactive nitrogen species (RNS). Appropriate amounts of ROS and RNS are responsible for regulating several physiological processes, such as proliferation, migration, differentiation, and metabolism [2]. However, excessive ROS and RNS may react with many biologically important molecules, including carbohydrates, lipids, proteins, and nucleic acids, and cause structural damage. This damage is often referred to as oxidative stress (OS) [3]. All animal species have to fight against various stressors that disrupt their homeostasis and respond to OS, which may be exacerbated due to environmental factors (such as pollution, radiation, consumption of certain drugs, cigarette smoke, and consumption of large amounts of alcohol) and physiological factors (such as ischemia, infection, physical or mental stress, and aging). In humans, OS may cause significant damage to cells and is associated with the occurrence and development of a variety of diseases, including cancer [4-6], neurodegenerative diseases (such as Alzheimer's disease and Parkinson's disease) [7-12], cardiovascular diseases [13-15], diabetes [16-18], etc. OS is also increasingly recognized as a contributing factor in various pathophysiological changes related to aging.

Therefore, it is crucial to identify specific OS-defense molecules. Many molecules can provide chemical protection against OS, commonly known as antioxidants. In the past decades, antioxidants have become the focus of attention.

\subsection{Background of Endogenous $\mathrm{H}_{2} \mathrm{~S}$}

Hydrogen sulfide $\left(\mathrm{H}_{2} \mathrm{~S}\right)$ is a kind of transparent toxic gas with a strong peculiar odor of rotten eggs [19]. At present, $\mathrm{H}_{2} \mathrm{~S}$ has been recognized as a third gaseous signaling 
molecule, similar to nitric oxide (NO) and carbon monoxide (CO) [20]. $\mathrm{H}_{2} \mathrm{~S}$ synthesized from $L$-cysteine in mammalian tissues can pass through the cell membrane directly without specific transporters. A small part of low-level $\mathrm{H}_{2} \mathrm{~S}$ can be converted into low-toxicity compounds through the cytosolic detoxification pathway, while most of them are oxidized and metabolized into sulfate and thiosulfate in mitochondria [21,22]. Within $24 \mathrm{~h}$, these metabolites are excreted through the kidneys, intestines, and lungs to maintain the balance of $\mathrm{H}_{2} \mathrm{~S}$ levels in the body [23]. A large amount of sulfide is stored in biomolecule-sulfide adducts; this pool could serve as a buffer of free biological sulfide concentrations due to the reversible nature of sulfide binding [24]. In fact, a large number of investigations reveal that, in most cells, tissues, and biological fluids, free sulfide represents less than $1 \%$ of the potentially available sulfide, indicating that endogenous sulfide pools should have large buffering capacities [25]. Physiological effects in response to $\mathrm{H}_{2} \mathrm{~S}$ typically display a bimodal response that is dependent on the concentration of $\mathrm{H}_{2} \mathrm{~S}$ [26]. Under physiological conditions, low concentrations of endogenous $\mathrm{H}_{2} \mathrm{~S}$ are not only nontoxic to cells, but have a protective effect. Precise control of endogenous $\mathrm{H}_{2} \mathrm{~S}$ production and metabolism is essential to maintain optimal cell function. Excessive production or lack thereof can lead to pathological changes.

\subsection{1. $\mathrm{H}_{2} \mathrm{~S}$ Synthetizing Enzymes}

$\mathrm{H}_{2} \mathrm{~S}$ is created enzymatically in humans via multiple conventional and unconventional pathways, of which three pathways are most prominent. These pathways use different enzymes, namely, cystathionine-beta-synthase (CBS), 3-mercaptopyruvate-sulfurtransferase (3-MST), and cystathionine-gamma-lyase (CSE), to create $\mathrm{H}_{2} \mathrm{~S}$ gas.

Cysteine serves as a sulfur source for various types of cofactors, such as coenzyme A, biotin, iron-sulfur (Fe-S) clusters, and the molybdenum cofactor; cysteine also plays a pivotal role in protein structure due to its high reactivity and ability to form disulfides in an oxidative environment [27]. CBS is a pyridoxal-5-phosphate-(PLP-)dependent enzyme. Besides producing $\mathrm{H}_{2} \mathrm{~S}$ from cysteine, $\mathrm{CBS}$ also catalyzes the condensation reaction of homocysteine [28]. In mammals, CBS mRNA and protein are primarily found in the liver, brain, kidney, and pancreas, not in all tissues [29,30], and are the main producer of $\mathrm{H}_{2} \mathrm{~S}$ in the central nervous system (CNS) [31]. CSE is expressed in all tissues, with the highest expression level in the liver and kidney [32-34]; it produces $\mathrm{H}_{2} \mathrm{~S}$ primarily via $\alpha, \beta$-elimination of cysteine, forming pyruvate and ammonia in the process [35], and it predominates in the thoracic aorta, ileum, portal vein, and uterus. 3-MST is involved in cysteine catabolism and initially produces an enzyme-bound persulfide via the desulfuration of 3-mercaptopyruvate [36]. However, most of the $\mathrm{H}_{2} \mathrm{~S}$ produced by 3-MST is bound in the form of sulfane sulfur, one of the forms in which endogenous $\mathrm{H}_{2} \mathrm{~S}$ is stored [37]. The combination of 3-MST and cysteine aminotransferase (CAT) can produce $\mathrm{H}_{2} \mathrm{~S}$ [38], and $D$-cysteine can also be used as a substrate to combine with D-amino acid oxidase (DAO) to produce $\mathrm{H}_{2} \mathrm{~S}$ [39]. CAT/ 3-MST is expressed in the CNS [40], while DAO/3MST mainly plays a role in the cerebellum and kidney [41]. Although these enzymes also exist in the surrounding tissues, up to now, only the first three endogenous $\mathrm{H}_{2} \mathrm{~S}$-synthesis pathways have been reported to be involved in retinal tissue, and there is no report on the DAO/3MST pathway in retinal tissue.

\subsection{2. $\mathrm{H}_{2} \mathrm{~S}$ Generation in Ocular Tissues}

In recent years, $\mathrm{H}_{2} \mathrm{~S}$ has been found in the mammalian retina, and it has been confirmed that the production of $\mathrm{H}_{2} \mathrm{~S}$ in eye tissue depends on four main enzymes: CSE, CBS, $3 \mathrm{MST}$, and CAT [38,42]. It is worth noting that these enzymes have also been shown to exist in different parts of eye tissue, especially the retina [43-45]. However, due to the different species and methods used in studies, the distribution and regulation of endogenous $\mathrm{H}_{2} \mathrm{~S}$ in ocular tissues are controversial.

As early as 2007, Pong et al. [44] discovered the expression and activity of CBS and CSE in the salamander retina, as well as the expression and activity of CSE in the mouse 
retina. In fact, endogenous $\mathrm{H}_{2} \mathrm{~S}$ production has been found in various tissues of bulls' eyes, including vitreous humor, cornea, aqueous humor, iris, ciliary muscle, lens, choroid, and retina. The highest level of endogenous $\mathrm{H}_{2} \mathrm{~S}$ was detected in the cornea and retina, while expression in the retina and optic nerve was slightly lower. The expression in the lens was relatively low, but it was not present in the vitreous humor. In 2011, Kulkarni et al. [46] studied the endogenous $\mathrm{H}_{2} \mathrm{~S}$-synthesis pathway in the bovine retina by using $\mathrm{H}_{2} \mathrm{~S}$ producing enzyme inhibitors. It was found that CBS or CSE inhibitors, or a combination of CBS and CSE inhibitors, could not completely block the production of endogenous $\mathrm{H}_{2} \mathrm{~S}$ in the bovine retina. The results suggested that, in addition to CSE and CBE, other enzymes may also participate in the production of endogenous $\mathrm{H}_{2} \mathrm{~S}$ in the bovine retina. In the same year, Mikami et al. [45] detected the expression of endogenous $\mathrm{H}_{2} \mathrm{~S}$-producing enzyme in each layer of the mouse retina by immunohistochemistry. The results showed that 3MST and CAT were expressed in the inner reticulum, outer plexiform layer, inner nuclear layer, outer nuclear layer, and the outer segment of photoreceptor, but the expression of CBS and CSE was not detected, which indicated that the generation of $\mathrm{H}_{2} \mathrm{~S}$ might be almost catalyzed by the CAT/3MST pathway in the mouse retina [45]. Subsequently, Gersztenkorn et al. in 2016 [47] further confirmed the expression of CBS, CSE, and 3MST proteins in the mouse retina by Western blot and immunohistochemistry. In 2019, Badiei Alireza et al. confirmed the expression of CBS and CSE transcripts in the canine retina by qRT-PCR. Furthermore, they confirmed the expression of CBS in rod cells, amacrine cells, and horizontal cells, and the expression of CSE in RPE, cone cells, and Müller cells by immunohistochemistry and Western blotting [48]. In our previous study, we also showed that endogenous $\mathrm{H}_{2} \mathrm{~S}$ synthesis increased through 3-MST in glaucoma animal models after seven weeks of elevated intraocular pressure. CBS is highly expressed in the early part of the entire life cycle and has a tendency towards retinal-dependent age growth. The activity of CSE can be tracked in the retinas of amphibians and mammals [44]. The 3MST/CAT pathway is the main way to produce $\mathrm{H}_{2} \mathrm{~S}$ in the mammalian retina, because both 3MST and CAT are located in retinal neurons [45]. The role of endogenous $\mathrm{H}_{2} \mathrm{~S}$ in the retina and its physiological role is unclear. However, strong evidence that retinal-derived $\mathrm{H}_{2} \mathrm{~S}$ has various effects on ocular tissues under physiological and pathological conditions, especially caused by its concentration. The abnormal expression of endogenous synthetases and the accumulation of substrates and intermediates can change the level of $\mathrm{H}_{2} \mathrm{~S}$ by an order of magnitude, resulting in structural or functional abnormalities in the eyes.

\subsubsection{Physiological Functions of $\mathrm{H}_{2} \mathrm{~S}$}

$\mathrm{H}_{2} \mathrm{~S}$ plays a key role in health as a recognized signal molecule and cell protectant. When the concentration of $\mathrm{H}_{2} \mathrm{~S}$ in tissues or cells is excessive, $\mathrm{H}_{2} \mathrm{~S}$ is considered to be a toxic substance, since it may cause cytotoxicity by inhibiting mitochondrial cytochrome $\mathrm{C}$ oxidase and destroying cell energy production, eventually leading to tissue inflammation or DNA damage [49]. Qu et al. [50] suggested that inhibiting the production of endogenous $\mathrm{H}_{2} \mathrm{~S}$ may be a potential neuroprotective strategy for strokes. The steady-state free $\mathrm{H}_{2} \mathrm{~S}$ concentration in homogenized mouse cells and tissues is estimated to range from 10-30 $\mathrm{nM}$ [51-53]. In tissues, when $\mathrm{H}_{2} \mathrm{~S}$ is produced at a physiological rate or its concentration is kept within a $\mu \mathrm{M}$ range, it can maintain the physiological functions of cells, such as cell division, DNA repair and metabolism, regulation of protein kinase, regulation of the cell cycle, and organization of the cytoskeleton [40]. The abnormal production and metabolism of $\mathrm{H}_{2} \mathrm{~S}$ are related to most neurodegenerative diseases [54]. In the $\mathrm{CNS}, \mathrm{H}_{2} \mathrm{~S}$ can promote long-term potentiation and regulate intracellular calcium concentration and $\mathrm{pH}$ in brain cells. The level of endogenous $\mathrm{H}_{2} \mathrm{~S}$ in bovine brain tissue and rat brain homogenization has been estimated at 50 to $160 \mu \mathrm{mol} / \mathrm{L}$ [55,56], concentrations high enough to suggest physiological functions. The antioxidant, antiapoptotic, and anti-inflammatory effects of $\mathrm{H}_{2} \mathrm{~S}$ have been found in animal or cellular models of Alzheimer's disease, Parkinson's disease, and vascular dementia. In addition, $\mathrm{H}_{2} \mathrm{~S}$ protects neurons from glutamic acid-mediated OS or OS by maintaining the pleiotropic effects of the cystine/glutamate antiporter, resulting in 
increased glutathione (GSH) levels in cells [57]. So far, all of it has not been fully elucidated. It is worth noting that almost all physiological aspects are affected by this gas transmitter.

\subsection{Exogenous Sources of $\mathrm{H}_{2} \mathrm{~S}$}

$\mathrm{Up}$ to now, various donors have released exogenous $\mathrm{H}_{2} \mathrm{~S}$, and the common ones are inorganic sulfides (such as $\mathrm{NaHS}$ and $\mathrm{Na}_{2} \mathrm{~S}$ ) and morpholin-4-ium-methoxyphenylmorpholino-phosphinodithioate (GYY4137). Among them, sulfide salts $\left(\mathrm{Na}_{2} \mathrm{~S}\right.$ and $\left.\mathrm{NaHS}\right)$ are the most widely used donors. These inorganic sulfide sources can generate $\mathrm{H}_{2} \mathrm{~S}$ instantaneously when they are dissolved, resulting in a rapid rise in the concentration of $\mathrm{H}_{2} \mathrm{~S}$ and then a rapid decline. However, GYY4137 slowly releases low but consistent concentrations of $\mathrm{H}_{2} \mathrm{~S}$. Therefore, some $\mathrm{H}_{2} \mathrm{~S}$ biological studies use this feature to simulate the time course of the physiological release of $\mathrm{H}_{2} \mathrm{~S}$ in vivo. It has been found that exogenous $\mathrm{H}_{2} \mathrm{~S}$ can prolong the life of worms, reduce inflammation, and promote the repair of damaged tissues [58]. Studies have found that a lack of $\mathrm{H}_{2} \mathrm{~S}$ or its substrate is associated with strabismus, myopia, cataract, optic atrophy, and retinal detachment [59-61]. Its exogenous donors have shown the potential to protect retinal ganglion cells (RGC) from diabetic retinopathy (DR), I/R injury, and $N$-methyl- $D$-aspartate (NMDA)-induced excitotoxicity [45-47]. In addition, our previous research found that GYY4137, as a sustained-release $\mathrm{H}_{2} \mathrm{~S}$ donor, can effectively protect RGC from different glaucoma damage in vitro and in vivo in a dose-dependent manner [62]. $\mathrm{H}_{2} \mathrm{~S}$ donors can regulate intraocular pressure, protect retinal cells, inhibit $\mathrm{OS}$, and reduce inflammation by regulating the function of proteins inside and outside the eye tissue. The potential value of $\mathrm{H}_{2} \mathrm{~S}$ against $\mathrm{OS}$ in human systems and its existence in mammalian eyes should be taken seriously [46]. This review focuses on the anti-OS effect of $\mathrm{H}_{2} \mathrm{~S}$ in retinal degenerative diseases and its potential mechanism, which paves the way for understanding the pathogenesis of retinal degenerative diseases and optimizing the application of $\mathrm{H}_{2} \mathrm{~S}$ donors in treatment.

\section{OS in Retinal Degenerative Disease}

OS is caused by the imbalance between ROS and the cellular antioxidant defense system in response to endogenous or exogenous stimuli. In fact, in addition to its role in cancer and diabetes, OS is considered to be key to the pathogenesis of many age-related diseases, such as atherosclerosis, cataracts, and Alzheimer's disease [63-65]. The theory of mitochondrial aging suggests that the accumulation of ROS with age will lead to greater cell damage, thereby linking aging, OS, and apoptosis to mediate cell death [66].

The retina is the most metabolically active tissue in the body, and the energy consumption per unit area of tissue is the highest [67]. Photoreceptors and retinal pigment epithelium (RPE) cells are rich in photosensitizers $[68,69]$. The excessive electromagnetic energy of photons is absorbed by these photosensitizers, and the bonds of other molecules can be destroyed by direct electron exchange or hydrogen exchange, resulting in excessive free radicals $[69,70]$. In an aerobic environment, oxygen molecules can generate ROS under the excitation of light, such as singlet oxygen, superoxide, and hydrogen peroxide $\left(\mathrm{H}_{2} \mathrm{O}_{2}\right)$ [71,72]. The increase in the ROS level may lead to OS injuries in photoreceptors and RPE cells [68,73]. In addition, the retina is widely exposed to light and high oxygen pressure, and its photoreceptors are rich in polyunsaturated fatty acids. Both of these substances make the neural retina vulnerable to oxidative damage, leading to mitochondrial dysfunction and mitochondrial DNA (mtDNA) damage. Even in the absence of disease, RPE cells will continue to be exposed to a considerable amount of OS [74]. Therefore, during the aging process, when the antioxidant capacity of RPE cells decreases, the balance between antioxidant and pro-oxidant factors is conducive to an increase in OS [75]. Excessive illumination can lead to photoreceptor degradation, and the cell death of the photoreceptor is irreversible damage caused by an increase in ROS and intracellular $\mathrm{Ca}^{2+}$ concentration. These pathological changes can trigger apoptosis [70,76]. These cellular mechanisms are related to the tissue effect of OS. More and more evidence shows that OS injury may be the first step to trigger the death of outer retinal neurons [70,77-80] and may 
be related to the pathology of retinal degenerative diseases, as shown in Figure 1. Studies on age-related eye disease (ARED) have shown that vitamin supplementation to control OS can delay disease progression and reduce severity [81].

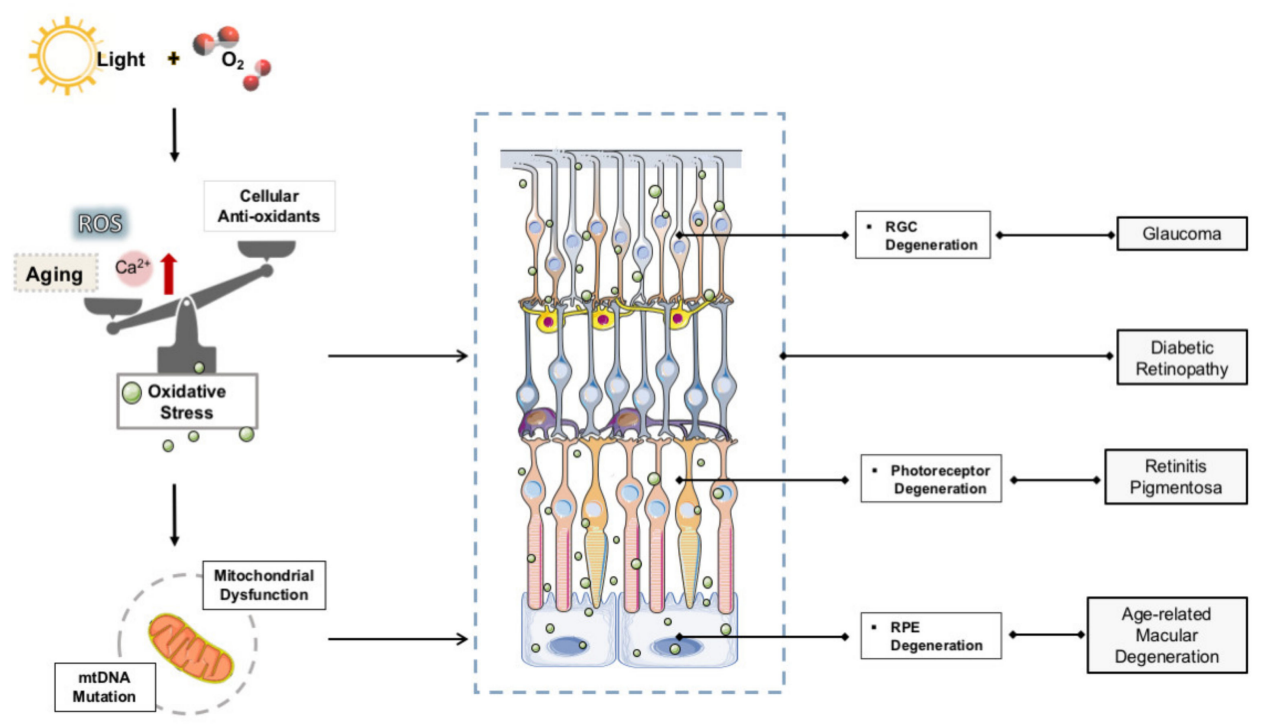

Figure 1. OS in retinal degenerative disease.

Age-related macular degeneration (AMD) leads to the loss of central vision, which is the main cause of blindness in the elderly and has an important impact on the quality of life. In AMD, the increases in ROS production, mitochondrial dysfunction, abnormal protein aggregation in the photoreceptor/RPE layer, and increased inflammation lead to OS and damage to RPE cells, which are considered to be key factors in the pathogenesis of AMD [82]. The increase of OS in RPE cells and the retina can lead to inflammation and further enhance the production of ROS in cells and tissues [83-85]. There are also studies suggesting that the oxygen-consuming mitochondria in the inner segment play a major role in the OS response of the outer retina [86-88].

Glaucoma is an optic neuropathy characterized by loss of RGC. RGC is the key link that transmits signals from the photoreceptor to the optic nerve. The loss of RGC will lead to a gradual loss of vision. In the I/R rat model, we observed that the apoptosis of RGC is related to the OS caused by the accumulation of glutamate [89,90]. Glaucoma also shows a similar pattern of cell damage associated with glutamate accumulation, which can be observed in other neurodegenerative diseases [91,92]. In addition, DNA damage in the trabecular meshwork (TM) by OS can cause anterior chamber aqueous drainage [93], which in turn leads to chronic changes in aqueous and vitreous humors in patients with glaucoma. Therefore, intraocular pressure is the main factor leading to the death of ganglion cells. The direct cause is axonal injury caused by high intraocular pressure, and the indirect cause is a ROS increase caused by RGC death under high intraocular pressure [93]. More interestingly, animal models have shown that age-related mitochondrial defects also play an important role in the pathogenesis of glaucoma [94,95].

DR is one of the most common complications of diabetes. Studies have shown that the activity of antioxidant enzymes in the retinas of diabetic patients is reduced, such as the superoxide dismutase (SOD), GSH reductase, GSH peroxidase, and catalase. In animal models, the administration of antioxidants or overexpression of SOD can protect retinal capillaries from hyperglycemia-induced degeneration. Therefore, ROS is considered to be the main factor involved in the occurrence of DR [94-96]. The main site of ROS production in mammalian cells is usually the respiratory transport chain of the mitochondrial inner membrane. Abnormal electron transfer caused by glucose metabolism disorder and excessive ROS triggers mitochondrial dysfunction and membrane potential $(\Delta \Psi \mathrm{m})$ reduction, 
which together cause mtDNA damage. mtDNA damage induces the synthesis of impaired respiratory chain proteins, thereby increasing the production of ROS, which can activate the nuclear factor- $\mathrm{kB}(\mathrm{NF}-\mathrm{kB})$ transcription factor, leading to the production of $\mathrm{NO}$ and proinflammatory cytokines. Superoxide production has been shown to be increased by uncoupling NO synthase. These superoxides react with NO to form peroxynitrite, which ultimately leads to cell damage and OS [97]. OS directly or indirectly induces inflammatory mediators, leading to retinal cell damage and the subsequent development of the pathogenesis of DR [98].

Retinitis pigmentosa (RP) is the most common degenerative photoreceptor hereditary eye disease characterized by progressive vision loss. Photoreceptors are composed of rod cells (about 95\%) and cone cells (only 5\%). The main energy comes from the oxidative metabolism of fatty acids. The cytotoxic effect due to the excessive oxygen content caused by a reduction in rod cells may lead to cone cell degeneration in the retina; therefore, OS damage is considered to be the primary cause of cone cell apoptosis and progressive vision loss [99]. OS is one of the most common causes of RP [100] and has also been reported to be associated with other eye diseases, such as AMD [101]. Some studies have confirmed that high levels of ROS in RPE and fatty acids are one of the molecular targets of eye diseases; the occurrence of eye diseases may be due to OS potentially altering transduction pathways and gene expression.

ROS, mainly peroxide and sulfenylated proteins, are inactivated by a variety of antioxidant mechanisms, which include compounds that directly react with ROS (e.g., GSH and ascorbate) and a complement of enzymes that either dismute ROS, e.g., SOD and catalase (Cat), or shuttle electrons from nicotinamide adenine dinucleotide phosphate (NADPH) to the oxidant or oxidized protein [102]. Many molecules can provide chemical protection against OS, commonly known as antioxidants. In the past decades, antioxidants have become a focus of attention. In the CNS, the use of antioxidants as complementary therapy seems promising to reduce nerve injury and improve response. As a kind of physiological signal molecule, $\mathrm{H}_{2} \mathrm{~S}$ has been widely studied recently. Some studies have shown that $\mathrm{H}_{2} \mathrm{~S}$ can be used as a neurotransmitter to regulate synaptic activity [103]. $\mathrm{H}_{2} \mathrm{~S}$ protects neurons from OS damage by increasing the level of GSH, the main antioxidant in cells [104]. Referring to the antioxidant effect of the $\mathrm{H}_{2} \mathrm{~S}$ donor on neurons, $\mathrm{H}_{2} \mathrm{~S}$ as a gas neuromodulator also plays an important role in regulating OS in the eyes.

\section{Effects of Endogenous $\mathrm{H}_{2} \mathrm{~S}$ on $\mathrm{OS}$ in Retinal Neurons}

Compared with exogenous antioxidants, endogenous antioxidants like GSH are much more promising, because they are our systematic scavengers with no additional side effects. At present, endogenous information molecules such as $\mathrm{CO}, \mathrm{NO}$, and $\mathrm{H}_{2} \mathrm{~S}$ are receiving more and more attention. $\mathrm{H}_{2} \mathrm{~S}$ itself is not a major cellular antioxidant, but $\mathrm{H}_{2} \mathrm{~S}$ can increase GSH by enhancing the activity of $\gamma$-glutamylcysteine synthase, thereby protecting cells from OS induced by glutamate and indirectly playing a strong antioxidant role. Earlier studies have shown that the cytoprotective function of $\mathrm{H}_{2} \mathrm{~S}$ involves its role in neuronal antioxidant defense.

GSH is one of the main sources of antioxidants in the retina. The Young-Jung Roh [105] et al. studies suggested that GSH depletion may cause unregulated OS to the cells in the retina and indeed increased cell death in the mouse retina. $\mathrm{H}_{2} \mathrm{~S}$ production is driven by CSE and CBS, the key enzymes that also drive the transsulfuration pathway (TSP) necessary for GSH production. Badiei et al. [91] revealed that CSE and CBS are expressed in the canine, nonhuman primate (NHP) and human retinas. In vitro silencing of CBS can reduce GSH level [106]. The expression of CBS protein in the synaptic layer of the retina increases with age [43], which is consistent with its role as a key enzyme in homocysteine metabolism because homocysteine levels also tend to increase with age [107], and it may contribute neuronal activity through the production of $\mathrm{GSH}$ and $\mathrm{H}_{2} \mathrm{~S}$ [48], suggesting that CBS has a protective effect on oxidative damage caused by aging. Compared with CBS, CSE levels did not increase with age. Since CBS can actively produce $\mathrm{H}_{2} \mathrm{~S}$ in the 
retina [108] and brain [109], the antioxidant activity of $\mathrm{H}_{2} \mathrm{~S}$ in the retina may be related to the age-dependent increase in CBS [104,110]. Compared with CSE, CBS has played a more active role in the production of $\mathrm{H}_{2} \mathrm{~S}$. RPE and Müller cells produce $\mathrm{GSH}$ and $\mathrm{H}_{2} \mathrm{~S}$ by CSE to help regulate the immune and inflammatory response of the retina, thereby protecting retinal nerve cells from OS [48]. However, $\mathrm{H}_{2} \mathrm{~S}$ enhances the transport of cysteine to increase GSH production to redistribute the localization of GSH to mitochondria, which protects the body against oxidative damage [109]. $\mathrm{H}_{2} \mathrm{~S}$ plays roles in antiapoptosis [62,111], anti-inflammatory and OS-suppressing activity [112,113]. These enzymes have potential protective effects on retinal redox $[45,114]$. Sulfur signaling is not limited to a "one and done" process as the sulfur can be transferred from the protein (which restores its original function) to another thiol such as cysteine or GSH and recycled [115]. $\mathrm{H}_{2} \mathrm{~S}$ may play an antioxidant and neuroprotective role in the retina [62,76,104].

$\mathrm{H}_{2} \mathrm{~S}$ can protect retinal neurons from light-induced degeneration by regulating $\mathrm{Ca}^{2+}$ influx. When retinal photoreceptor cells were exposed to light, intracellular $\mathrm{Ca}^{2+}$ concentration is reduced to $10 \mathrm{~nm}$, which activated the 3MST / CAT pathway to produce $\mathrm{H}_{2} \mathrm{~S}$. In the dark, the concentration of $\mathrm{Ca}^{2+}$ increased to $600 \mathrm{~nm}$, resulting in the cessation of $\mathrm{H}_{2} \mathrm{~S}$ production. $\mathrm{H}_{2} \mathrm{~S}$ can protect photoreceptor cells from the effects of apoptosis and OS in retinal cells by activating the vacuolar H+-ATPase (V-ATPase) in horizontal cells, which could activate L-type calcium channels (VGCC) to maintain the intracellular calcium balance in photoreceptor cells. Excessive illumination leads to photoreceptor degradation, and its death is irreversible damage caused by ROS and intracellular calcium concentration. Under excessive illumination conditions, endogenous $\mathrm{H}_{2} \mathrm{~S}$ regulation of $\mathrm{Ca}^{2+}$ may fail and lead to photoreceptor cell degeneration. Even in this case, the degradation of photoreceptors was inhibited by the administration of an $\mathrm{H}_{2} \mathrm{~S}$ donor. Under strong light, the increase in the number of TUNEL- and 8-hydroxy-2'-deoxyguanosine-positive cells was suppressed by $\mathrm{H}_{2} \mathrm{~S}$ administration [45]. Enhancing the 3MST/CAT pathway or giving $\mathrm{H}_{2} \mathrm{~S}$ may have clinical benefits for retinal cell degeneration diseases.

Kimura et al. [104] showed that $\mathrm{H}_{2} \mathrm{~S}$ can increase the production of GSH to protect cells from OS by enhancing the cysteine/cysteine transporters and redistributing GSH to mitochondria. In addition, the production of $\mathrm{H}_{2} \mathrm{~S}$ in mitochondria may directly inhibit OS. In mitochondria, $\mathrm{H}_{2} \mathrm{~S}$ plays a protective role by inhibiting the activity of cytochrome oxidase, upregulating the level of SOD and downregulating the level of ROS after I/R. $\mathrm{H}_{2} \mathrm{~S}$ also plays a neuroprotective role by increasing the production of GSH and regulating the transport of CSE to mitochondria and the supply of ATP during hypoxia, as shown in Figure 2.

A

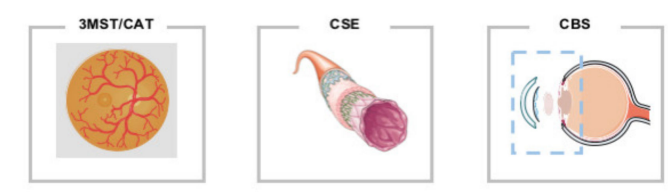

B

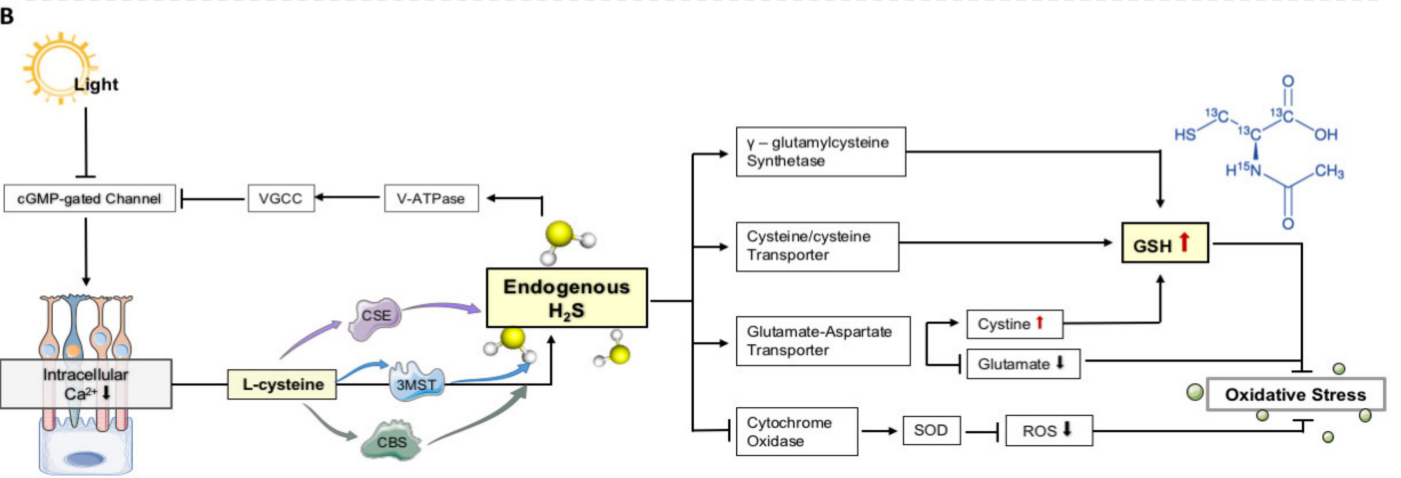

Figure 2. Endogenous $\mathrm{H}_{2} \mathrm{~S}$ on $\mathrm{OS}$ in retinal neurons. (A) The production of $\mathrm{H}_{2} \mathrm{~S}$ in eye tissue depends on three main channels. (B) Effects of endogenous $\mathrm{H}_{2} \mathrm{~S}$ on $\mathrm{OS}$ in retinal neurons. 
The glutamate-aspartate transporter in retinoblasts is also involved in maintaining GSH levels [116]. Microglia are the main immune cells in the retina. The aging changes that occur in aging microglia may endow the retina with age-dependent disease vulnerability $[117,118]$. Glutamate can enhance neurodegeneration induced by cytokines by activating microglia [119]. Glutamate excitotoxicity and associated endoplasmic-reticulum stress conditions are caused by a cascade of events that interfere with the operation of the glutamatergic system, which always lead to microglia activation and inflammation. However, $\mathrm{H}_{2} \mathrm{~S}$ therapy may alleviate the above-mentioned stress conditions, and its potential therapeutic target may be the regulation of retinal neurotransmission transporters related to glutamate excitotoxicity. Glutamate shares the same amino acid transporter with cystine, and it competes with cystine for transport into cells [120]. Therefore, in the process of glutamate excitotoxicity mediated by OS, elevated extracellular glutamate inhibits the transport of cystine [57]. Cystine is the primary source of intracellular cysteine necessary for GSH synthesis. The decrease in cysteine input leads to the decrease in GSH synthesis. It seems that $\mathrm{H}_{2} \mathrm{~S}$ can restore glutamic acid-inhibited cystine input. In short, $\mathrm{H}_{2} \mathrm{~S}$ treatment may reduce glutamate excitotoxicity, endoplasmic-reticulum stress and microglia activation, which are related to OS.

\section{Effects of Exogenous $\mathrm{H}_{2} \mathrm{~S}$ on $\mathrm{OS}$ in Retinal Neurons}

In previous studies by different research groups, including us, exogenous donors have shown therapeutic potential in a variety of retinal diseases. The neuroprotective effect of $\mathrm{H}_{2} \mathrm{~S}$ may be related to the inhibition of glial cell activation, inhibition of pro-inflammatory pathway, inhibition of inflammatory response, reduction of OS, and downregulation of retinal autophagy [62,111,121].

NADPH oxidase is the main source of ROS and plays a key role in the aggravation of retinal OS in glaucoma models [122]. Results showed that the activity of NADPH oxidase in the retinas of experimental glaucoma rats was inhibited by exogenous donor NaHS [111]. Mitochondria maintain basic energy metabolism mainly through oxidative phosphorylation. The cellular ATP content and oxygen-consumption capacity produced by the mitochondrial respiratory chain can reflect the integrity of mitochondrial function. Mitochondrial dysfunction even contributes to the accumulation of ROS, which aggravates OS. NaHS treatment can effectively restore mitochondrial function in RGC in experimental glaucoma [111]. NaHS treatment in the retina of streptozotocin-induced diabetic rats also attenuated mitochondrial dysfunction [123]. Huang et al. [121] have shown that NaHS can inhibit the activity of the erk1/2 pathway, inhibit the activity of NADPH oxidase, and inhibit the activation of glial cells, as shown in Figure 3.

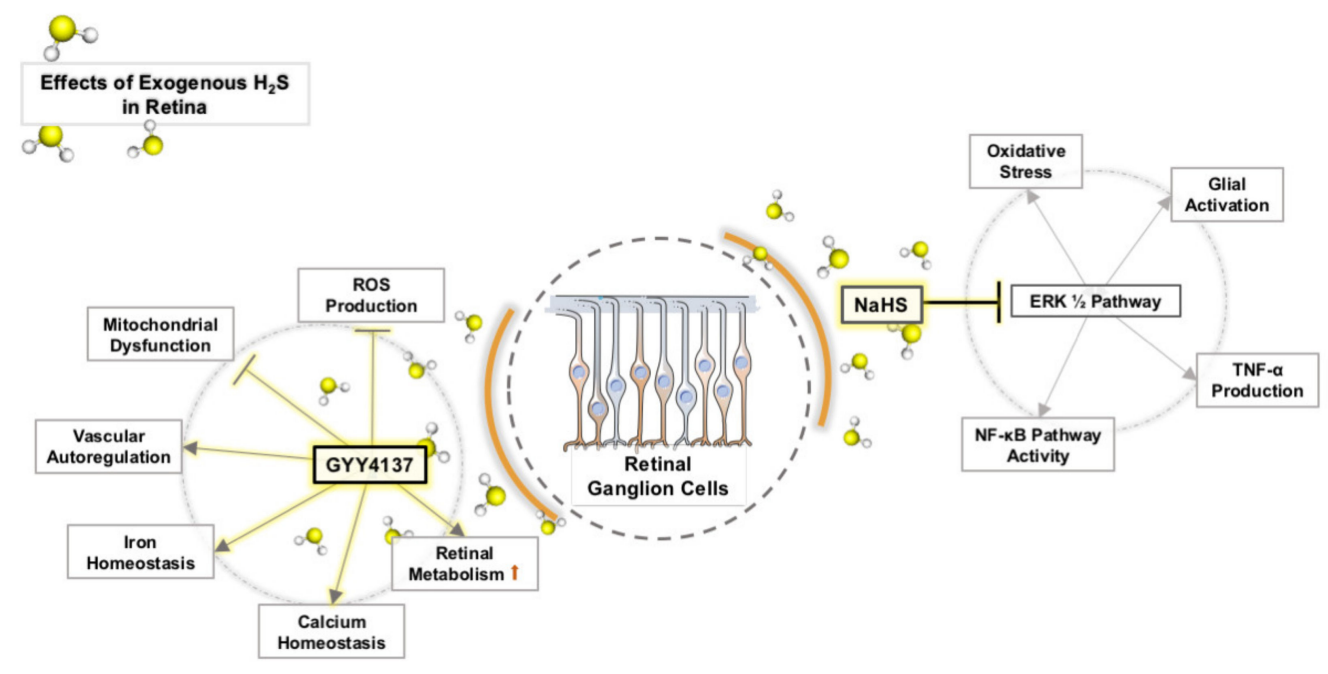

Figure 3. Effects of exogenous $\mathrm{H}_{2} \mathrm{~S}$ on $\mathrm{OS}$ in retinal neurons. 
GYY4137 is a sustained-release $\mathrm{H}_{2} \mathrm{~S}$ donor. We observed that $100 \mathrm{mM} \mathrm{H}_{2} \mathrm{O}_{2}$ induced significant $O S$ in retinal explants of the experimental glaucoma model. However, the addition of $100 \mathrm{nM}$ and $10 \mu \mathrm{M}$ GYY4137 can significantly increase the survival rate of RGC, although $1 \mathrm{nM} \mathrm{GYY4137}$ has no protective effect on $100 \mathrm{mM} \mathrm{H}_{2} \mathrm{O}_{2}$. At a certain concentration, GYY4137 can reduce the damage of OS to RGCs (Figure 3). Our study found that GYY4137 has a concentration-dependent neuroprotective effect on glaucomatous retinal damage caused by OS in vitro. Generally, a higher concentration is required to preserve RGCs, and the optimal concentration is $100 \mathrm{nM} \mathrm{[62].}$

Synuclein is a small protein family, including $\alpha$ (SNCA), $\beta$ (SNCB), and c (SNCG) synuclein $[124,125]$, which are involved in various neurodegeneration effects of the CNS. The misfolding and aggregation of SNCA is directly related to the activation of microglia, and the subsequent inflammation and OS lead to neurodegeneration [126]. Synuclein is present in the retina and optic nerve [127]. Under physiological conditions, SNCB is considered to be a physiological inhibitor of SNCA and an antiaggregation agent with neuroprotective effects. However, the protective effect of SNCB is exerted in a dosedependent manner [124], which means that the overexpression and accumulation of SNCB will increase OS and inflammation and promote cell apoptosis $[128,129]$. SNCB was found to form toxic cytoplasmic inclusion bodies in a manner similar to SNCA and has similar toxic mechanisms, including vesicle transport damage and OS induction [130]. $\mathrm{H}_{2} \mathrm{~S}$ is involved in some pathophysiological processes that interact with SNCB, such as microglia activation, p53-mediated apoptosis, inflammatory response, and free radical reaction [121,131-133].

Our research shows that increasing exogenous $\mathrm{H}_{2} \mathrm{~S}$ can effectively downregulate rat retinal SNCB and has a protective effect on retinal neurons [134]. Therefore, removing the pathogenic $\mathrm{SNCB}$ or reducing its abundance may be an effective way to rescue neurons and prevent the progression of glaucoma. $\mathrm{H}_{2} \mathrm{~S}$ protects retinal neurons from excessive OS $[45,63,123]$, which further confirms that the reduction of OS may be involved in the neuroprotective effect of $\mathrm{H}_{2} \mathrm{~S}$ supplementation on RGCs in glaucoma.

In our previous studies, we have also revealed that exogenous $\mathrm{H}_{2} \mathrm{~S}$ activates the pathways related to OS, such as iron regulation, ROS clearance, and mitochondrial homeostasis and function [135]. Vitamin C also plays an important role as an antioxidant in the retina and brain [136]. Vitamin C is mainly transported across the blood-retinal barrier (BRB) as dehydroascorbic acid (DHA), mediated through facilitative glucose transporters (GLUT)1, and accumulates as ascorbic acid (AA) in the rat retina $[137,138]$. The transporters in the $\mathrm{BRB}$ play a role in exogenous $\mathrm{H}_{2} \mathrm{~S}$ donor delivery. Because the $\mathrm{BRB}$ regulates the transfer of small molecules from the eye outwards (intravitreal injection) and inwards into the eye (systemic, topical (trans-scleral route), subconjunctival, and suprachoroidal administration) [139]. Although understanding of the active drug transport in the BRB is still far from complete, there is evidence for the role of some transporters in drug delivery, these transporters include MRP1 [140-143], MRP2 [144,145], MRP5 [141], P-gp [142,146,147], and BCRP [145]. DHA is a transportable form across the inner BRB; the transport and reduction of DHA in Müller cells plays an important role in the maintenance of a healthy retina [148]. Slc2a1 promotes DHA to be transported through the inner BRB [149]. The downregulation of Slc2a1 levels leads to a corresponding downregulation of vitamin $C$ transport. Downregulation of vitamin $C$ transport will affect the antioxidant properties of the retina, which will contribute to neuronal death under OS [150]. We have observed that exogenous $\mathrm{H}_{2} \mathrm{~S}$ can increase the transport of vitamin $\mathrm{C}$ by restoring the level of Slc2a1, thereby enhancing the antioxidant properties of the retina [130]. The metabolism and regulation of iron are crucial in mammals. Excessive iron may catalyze the formation of highly active hydroxyl radicals and ultimately induce the accumulation of ROS [151,152]. Glrx3 is a single-mercapto GSH that uses the reducing power of GSH to maintain and regulate the redox state of cells, which is necessary for the assembly of Fe-S clusters [153,154]. Meanwhile Glrx3 can form a (2Fe-2S) cluster bridged dimer, transfer Fe-S clusters to receptor proteins $[155,156]$, and regulate cellular iron homeostasis $[157,158]$. In our experiment, we found that $\mathrm{H}_{2} \mathrm{~S}$ can 
significantly upregulate Glrx3 [135]. Overexpression of Glrx3 can make up for the lack of other reduction equivalents [158]. Most of the iron in the human body is contained in the protoporphyrin ring of heme [152]. Heme degradation is very important in maintaining iron homeostasis and preventing its cytotoxicity and OS [159]. Cyb5r3 is the main reductase in mitochondria and heme reductase, which can recover oxidized heme $\left(\mathrm{Fe}^{3+}\right)$ to reduced form $\left(\mathrm{Fe}^{2+}\right)$ [160]. $\mathrm{H}_{2} \mathrm{~S}$ plays a reducing role similar to that of $\mathrm{Cyb5r3}$ in cycling oxidized heme to the reduced state [135]. Under the conditions of I/ $\mathrm{R}, \mathrm{H}_{2} \mathrm{~S}$ can effectively inhibit oxidative phosphorylation and limit the utilization of glucose as an energy source, thereby increasing intracellular oxygen tension during ischemia and limiting the production of ROS during reperfusion. $\mathrm{H}_{2} \mathrm{~S}$ promotes the use of ketone bodies as an alternative energy source and maintains the production of ATP. Metabolic stress usually exhausts the elasticity of neurons and leads to the loss of neuronal cells. Obviously, $\mathrm{H}_{2} \mathrm{~S}$ enhances the ability of retinal neurons to resist I/R-induced metabolic stress [135].

\section{Conclusions}

It is well known that OS-mediated inflammatory processes in the eyes of susceptible hosts can lead to the initiation of subtle pathological changes, which trigger a degenerative and inflammatory cascade in the retina. $\mathrm{H}_{2} \mathrm{~S}$ and its donors, as a regulator of OS in retinal degenerative diseases, can alleviate retinopathy by inhibiting the harmful effects of OS. It seems that further research will greatly improve our understanding of the pathophysiological mechanisms of retinal degenerative diseases and the potential for the treatment of retinal diseases associated with $\mathrm{H}_{2} \mathrm{~S}$.

Author Contributions: Writing—original draft preparation, P.L., H.L. and V.P.; writing—review and editing, P.L. and X.S.; visualization, P.L. and H.L.; supervision, V.P. All authors have read and agreed to the published version of the manuscript.

Funding: This research was funded by Deutsche forschungsgemeinschaft, grant number PR1569/1-1".

Institutional Review Board Statement: Not applicable.

Informed Consent Statement: Not applicable.

Data Availability Statement: Not applicable.

Acknowledgments: The authors gratefully acknowledge scholarship financial support from the China Scholarship Council.

Conflicts of Interest: The authors declare no conflict of interest.

\section{References}

1. Davies, K.J. Oxidative stress: The paradox of aerobic life. Biochem. Soc. Symp. 1995, 61, 1-31. [CrossRef]

2. Griendling, K.K.; Touyz, R.M.; Zweier, J.L.; Dikalov, S.; Chilian, W.; Chen, Y.R.; Harrison, D.G.; Bhatnagar, A.; American Heart Association Council on Basic Cardiovascular Sciences. Measurement of Reactive Oxygen Species, Reactive Nitrogen Species, and Redox-Dependent Signaling in the Cardiovascular System: A Scientific Statement from the American Heart Association. Circ. Res. 2016, 119, e39-e75. [CrossRef] [PubMed]

3. Aprioku, J.S. Pharmacology of free radicals and the impact of reactive oxygen species on the testis. J. Reprod. Infertil. 2013, 14, 158-172. [PubMed]

4. Thanan, R.; Oikawa, S.; Hiraku, Y.; Ohnishi, S.; Ma, N.; Pinlaor, S.; Yongvanit, P.; Kawanishi, S.; Murata, M. Oxidative stress and its significant roles in neurodegenerative diseases and cancer. Int. J. Mol. Sci. 2014, 16, 193-217. [CrossRef]

5. Filaire, E.; Dupuis, C.; Galvaing, G.; Aubreton, S.; Laurent, H.; Ruddy, R.; Marc, F. Lung cancer: What are the links with oxidative stress, physical activity and nutrition. Lung Cancer 2013, 82, 383-389. [CrossRef]

6. Paschos, A.; Pandya, R.; Duivenvoorden, W.C.; Pinthus, J.H. Oxidative stress in prostate cancer: Changing research concepts towards a novel paradigm for prevention and therapeutics. Prostate Cancer Prostatic Dis. 2013, 16, 217-225. [CrossRef] [PubMed]

7. Blesa, J.; Trigo-Damas, I.; Quiroga-Varela, A.; Jackson-Lewis, V.R. Oxidative stress and Parkinson's disease. Front. Neuroanat. 2015, 9, 91. [CrossRef] [PubMed]

8. Sharma, N.; Nehru, B. Characterization of the lipopolysaccharide induced model of Parkinson's disease: Role of oxidative stress and neuroinflammation. Neurochem. Int. 2015, 87, 92-105. [CrossRef] [PubMed]

9. Gaki, G.S.; Papavassiliou, A.G. Oxidative stress-induced signaling pathways implicated in the pathogenesis of Parkinson's disease. Neuromol. Med. 2014, 16, 217-230. [CrossRef] [PubMed] 
10. Swomley, A.M.; Butterfield, D.A. Oxidative stress in Alzheimer disease and mild cognitive impairment: Evidence from human data provided by redox proteomics. Arch. Toxicol. 2015, 89, 1669-1680. [CrossRef] [PubMed]

11. Mota, S.I.; Costa, R.O.; Ferreira, I.L.; Santana, I.; Caldeira, G.L.; Padovano, C.; Fonseca, A.C.; Baldeiras, I.; Cunha, C.; Letra, L.; et al. Oxidative stress involving changes in Nrf2 and ER stress in early stages of Alzheimer's disease. Biochim. Biophys. Acta Mol. Basis Dis. 2015, 1852, 1428-1441. [CrossRef] [PubMed]

12. Meraz-Rios, M.A.; Franco-Bocanegra, D.; Toral Rios, D.; Campos-Pena, V. Early onset Alzheimer's disease and oxidative stress. Oxid. Med. Cell. Longev. 2014, 2014, 375968. [CrossRef] [PubMed]

13. Siti, H.N.; Kamisah, Y.; Kamsiah, J. The role of oxidative stress, antioxidants and vascular inflammation in cardiovascular disease (a review). Vascul. Pharmacol. 2015, 71, 40-56. [CrossRef]

14. Popolo, A.; Autore, G.; Pinto, A.; Marzocco, S. Oxidative stress in patients with cardiovascular disease and chronic renal failure. Free Radic. Res. 2013, 47, 346-356. [CrossRef] [PubMed]

15. Miller, M.R.; Shaw, C.A.; Langrish, J.P. From particles to patients: Oxidative stress and the cardiovascular effects of air pollution. Future Cardiol. 2012, 8, 577-602. [CrossRef] [PubMed]

16. Rosales-Corral, S.; Tan, D.X.; Manchester, L.; Reiter, R.J. Diabetes and Alzheimer disease, two overlapping pathologies with the same background: Oxidative stress. Oxid. Med. Cell. Longev. 2015, 2015, 985845. [CrossRef] [PubMed]

17. Zephy, D.; Ahmad, J. Type 2 diabetes mellitus: Role of melatonin and oxidative stress. Diabetes Metab. Syndr. 2015, 9, 127-131. [CrossRef]

18. Maiese, K. New Insights for Oxidative Stress and Diabetes Mellitus. Oxid. Med. Cell. Longev. 2015, 2015, 875961. [CrossRef]

19. Wang, R. Hydrogen sulfide: The third gasotransmitter in biology and medicine. Antioxid. Redox Signal. 2010, 12, 1061-1064. [CrossRef]

20. Wang, R. Gasotransmitters: Growing pains and joys. Trends Biochem. Sci. 2014, 39, 227-232. [CrossRef]

21. Chen, C.Q.; Xin, H.; Zhu, Y.Z. Hydrogen sulfide: Third gaseous transmitter, but with great pharmacological potential. Acta Pharmacol. Sin. 2007, 28, 1709-1716. [CrossRef]

22. Stipanuk, M.H.; Ueki, I. Dealing with methionine/homocysteine sulfur: Cysteine metabolism to taurine and inorganic sulfur. J. Inherit. Metab. Dis. 2011, 34, 17-32. [CrossRef]

23. Furne, J.; Springfield, J.; Koenig, T.; DeMaster, E.; Levitt, M.D. Oxidation of hydrogen sulfide and methanethiol to thiosulfate by rat tissues: A specialized function of the colonic mucosa. Biochem. Pharmacol. 2001, 62, 255-259. [CrossRef]

24. Nagy, P.; Palinkas, Z.; Nagy, A.; Budai, B.; Toth, I.; Vasas, A. Chemical aspects of hydrogen sulfide measurements in physiological samples. Biochim. Biophys. Acta Mol. Basis Dis. 2014, 1840, 876-891. [CrossRef] [PubMed]

25. Nagy, P. Mechanistic chemical perspective of hydrogen sulfide signaling. Methods Enzymol. 2015, 554, 3-29. [CrossRef]

26. Landry, A.P.; Ballou, D.P.; Banerjee, R. Hydrogen Sulfide Oxidation by Sulfide Quinone Oxidoreductase. Chembiochem 2021, 22, 949-960. [CrossRef] [PubMed]

27. Nagy, P. Kinetics and mechanisms of thiol-disulfide exchange covering direct substitution and thiol oxidation-mediated pathways. Antioxid. Redox Signal. 2013, 18, 1623-1641. [CrossRef] [PubMed]

28. Singh, S.; Banerjee, R. PLP-dependent H(2)S biogenesis. Biochim. Biophys. Acta 2011, 1814, 1518-1527. [CrossRef] [PubMed]

29. Martin, G.R.; McKnight, G.W.; Dicay, M.S.; Coffin, C.S.; Ferraz, J.G.; Wallace, J.L. Hydrogen sulphide synthesis in the rat and mouse gastrointestinal tract. Dig. Liver Dis. 2010, 42, 103-109. [CrossRef]

30. Zhao, W.; Zhang, J.; Lu, Y.; Wang, R. The vaso relaxant effect of H2S as a novel endogenous gaseous KATP channel opener. EMBO J. 2001, 20, 6008-6016. [CrossRef]

31. Abe, K.; Kimura, H. The possible role of hydrogen sulfide as an endogenous neuromodulator. J. Neurosci. 1996, 16, 1066-1071. [CrossRef] [PubMed]

32. Han, S.J.; Noh, M.R.; Jung, J.M.; Ishii, I.; Yoo, J.; Kim, J.I.; Park, K.M. Hydrogen sulfide-producing cystathionine gamma-lyase is critical in the progression of kidney fibrosis. Free Radic. Biol. Med. 2017, 112, 423-432. [CrossRef] [PubMed]

33. Hu, L.F.; Lu, M.; Hon Wong, P.T.; Bian, J.S. Hydrogen sulfide: Neurophysiology and neuropathology. Antioxid. Redox Signal. 2011, 15, 405-419. [CrossRef] [PubMed]

34. Ohno, K.; Ito, M.; Ichihara, M.; Ito, M. Molecular hydrogen as an emerging therapeutic medical gas for neurodegenerative and other diseases. Oxid. Med. Cell. Longev. 2012, 2012, 353152. [CrossRef] [PubMed]

35. Chiku, T.; Padovani, D.; Zhu, W.; Singh, S.; Vitvitsky, V.; Banerjee, R. $\mathrm{H}_{2} \mathrm{~S}$ biogenesis by human cystathionine gamma-lyase leads to the novel sulfur metabolites lanthionine and homolanthionine and is responsive to the grade of hyperhomocysteinemia. J. Biol. Chem. 2009, 284, 11601-11612. [CrossRef]

36. Yadav, P.K.; Yamada, K.; Chiku, T.; Koutmos, M.; Banerjee, R. Structure and kinetic analysis of H2S production by human mercaptopyruvate sulfurtransferase. J. Biol. Chem. 2013, 288, 20002-20013. [CrossRef]

37. Yadav, P.K.; Vitvitsky, V.; Carballal, S.; Seravalli, J.; Banerjee, R. Thioredoxin regulates human mercaptopyruvate sulfurtransferase at physiologically-relevant concentrations. J. Biol. Chem. 2020, 295, 6299-6311. [CrossRef]

38. Hughes, M.N.; Centelles, M.N.; Moore, K.P. Making and working with hydrogen sulfide: The chemistry and generation of hydrogen sulfide in vitro and its measurement in vivo: A review. Free Radic. Biol. Med. 2009, 47, 1346-1353. [CrossRef]

39. Shibuya, N.; Koike, S.; Tanaka, M.; Ishigami-Yuasa, M.; Kimura, Y.; Ogasawara, Y.; Fukui, K.; Nagahara, N.; Kimura, H. A novel pathway for the production of hydrogen sulfide from D-cysteine in mammalian cells. Nat. Commun. 2013, 4, 1366. [CrossRef] 
40. Szabo, C. A timeline of hydrogen sulfide (H2S) research: From environmental toxin to biological mediator. Biochem. Pharmacol. 2018, 149, 5-19. [CrossRef]

41. Paul, B.D.; Snyder, S.H. $\mathrm{H}_{2} \mathrm{~S}$ signaling through protein sulfhydration and beyond. Nat. Rev. Mol. Cell Biol 2012, 13, 499-507. [CrossRef]

42. Tanizawa, K. Production of H2S by 3-mercaptopyruvate sulphurtransferase. J. Biochem. 2011, 149, 357-359. [CrossRef] [PubMed]

43. Persa, C.; Osmotherly, K.; Chao-Wei Chen, K.; Moon, S.; Lou, M.F. The distribution of cystathionine beta-synthase (CBS) in the eye: Implication of the presence of a trans-sulfuration pathway for oxidative stress defense. Exp. Eye Res. 2006, 83, 817-823. [CrossRef] [PubMed]

44. Pong, W.W.; Stouracova, R.; Frank, N.; Kraus, J.P.; Eldred, W.D. Comparative localization of cystathionine beta-synthase and cystathionine gamma-lyase in retina: Differences between amphibians and mammals. J. Comp. Neurol 2007, 505, 158-165. [CrossRef] [PubMed]

45. Mikami, Y.; Shibuya, N.; Kimura, Y.; Nagahara, N.; Yamada, M.; Kimura, H. Hydrogen sulfide protects the retina from lightinduced degeneration by the modulation of Ca2+ influx. J. Biol. Chem. 2011, 286, 39379-39386. [CrossRef]

46. Kulkarni, M.; Njie-Mbye, Y.F.; Okpobiri, I.; Zhao, M.; Opere, C.A.; Ohia, S.E. Endogenous production of hydrogen sulfide in isolated bovine eye. Neurochem. Res. 2011, 36, 1540-1545. [CrossRef]

47. Gersztenkorn, D.; Coletta, C.; Zhu, S.; Ha, Y.; Liu, H.; Tie, H.; Zhou, J.; Szabo, C.; Zhang, W.; Motamedi, M. Hydrogen Sulfide Contributes to Retinal Neovascularization in Ischemia-Induced Retinopathy. Investig. Ophthalmol. Vis. Sci. 2016, 57, 3002-3009. [CrossRef]

48. Badiei, A.; Sudharsan, R.; Santana, E.; Dunaief, J.L.; Aguirre, G.D. Comparative localization of cystathionine beta synthases and cystathionine gamma lyase in canine, non-human primate and human retina. Exp. Eye Res. 2019, 181, 72-84. [CrossRef]

49. Reiffenstein, R.J.; Hulbert, W.C.; Roth, S.H. Toxicology of hydrogen sulfide. Annu. Rev. Pharmacol. Toxicol. 1992, 32, 109-134. [CrossRef]

50. Qu, K.; Chen, C.P.; Halliwell, B.; Moore, P.K.; Wong, P.T. Hydrogen sulfide is a mediator of cerebral ischemic damage. Stroke 2006, 37, 889-893. [CrossRef]

51. Vitvitsky, V.; Kabil, O.; Banerjee, R. High turnover rates for hydrogen sulfide allow for rapid regulation of its tissue concentrations. Antioxid. Redox Signal. 2012, 17, 22-31. [CrossRef]

52. Furne, J.; Saeed, A.; Levitt, M.D. Whole tissue hydrogen sulfide concentrations are orders of magnitude lower than presently accepted values. Am. J. Physiol. Regul. Integr. Comp. Physiol. 2008, 295, R1479-R1485. [CrossRef] [PubMed]

53. Levitt, M.D.; Abdel-Rehim, M.S.; Furne, J. Free and acid-labile hydrogen sulfide concentrations in mouse tissues: Anomalously high free hydrogen sulfide in aortic tissue. Antioxid. Redox Signal. 2011, 15, 373-378. [CrossRef]

54. Gong, Q.H.; Shi, X.R.; Hong, Z.Y.; Pan, L.L.; Liu, X.H.; Zhu, Y.Z. A new hope for neurodegeneration: Possible role of hydrogen sulfide. J. Alzheimers Dis. 2011, 24 (Suppl. S2), 173-182. [CrossRef]

55. Savage, J.C.; Gould, D.H. Determination of sulfide in brain tissue and rumen fluid by ion-interaction reversed-phase highperformance liquid chromatography. J. Chromatogr. 1990, 526, 540-545. [CrossRef]

56. Goodwin, L.R.; Francom, D.; Dieken, F.P.; Taylor, J.D.; Warenycia, M.W.; Reiffenstein, R.J.; Dowling, G. Determination of sulfide in brain tissue by gas dialysis/ion chromatography: Postmortem studies and two case reports. J. Anal. Toxicol. 1989, 13, 105-109. [CrossRef] [PubMed]

57. Kimura, Y.; Kimura, H. Hydrogen sulfide protects neurons from oxidative stress. FASEB J. 2004, 18, 1165-1167. [CrossRef]

58. Gemici, B.; Wallace, J.L. Anti-inflammatory and cytoprotective properties of hydrogen sulfide. Methods Enzymol. 2015, 555, 169-193. [CrossRef]

59. Yu, M.; Sturgill-Short, G.; Ganapathy, P.; Tawfik, A.; Peachey, N.S.; Smith, S.B. Age-related changes in visual function in cystathionine-beta-synthase mutant mice, a model of hyperhomocysteinemia. Exp. Eye Res. 2012, 96, 124-131. [CrossRef]

60. Ganapathy, P.S.; Moister, B.; Roon, P.; Mysona, B.A.; Duplantier, J.; Dun, Y.; Moister, T.K.; Farley, M.J.; Prasad, P.D.; Liu, K.; et al. Endogenous elevation of homocysteine induces retinal neuron death in the cystathionine-beta-synthase mutant mouse. Investig. Ophthalmol. Vis. Sci. 2009, 50, 4460-4470. [CrossRef]

61. Tawfik, A.; Markand, S.; Al-Shabrawey, M.; Mayo, J.N.; Reynolds, J.; Bearden, S.E.; Ganapathy, V.; Smith, S.B. Alterations of retinal vasculature in cystathionine-beta-synthase heterozygous mice: A model of mild to moderate hyperhomocysteinemia. Am. J. Pathol. 2014, 184, 2573-2585. [CrossRef]

62. Liu, H.; Anders, F.; Thanos, S.; Mann, C.; Liu, A.; Grus, F.H.; Pfeiffer, N.; Prokosch-Willing, V. Hydrogen Sulfide Protects Retinal Ganglion Cells Against Glaucomatous Injury In Vitro and In Vivo. Investig. Ophthalmol. Vis. Sci. 2017, 58, 5129-5141. [CrossRef] [PubMed]

63. Knekt, P.; Heliovaara, M.; Rissanen, A.; Aromaa, A.; Aaran, R.K. Serum antioxidant vitamins and risk of cataract. BMJ 1992, 305, 1392-1394. [CrossRef] [PubMed]

64. Dusting, G.J.; Triggle, C. Are we over oxidized? Oxidative stress, cardiovascular disease, and the future of intervention studies with antioxidants. Vasc. Health Risk Manag. 2005, 1, 93-97. [CrossRef] [PubMed]

65. Nunomura, A.; Moreira, P.I.; Lee, H.G.; Zhu, X.; Castellani, R.J.; Smith, M.A.; Perry, G. Neuronal Death and Survival Under Oxidative Stress in Alzheimer and Parkinson Diseases. CNS Neurol. Disord. Drug Targets 2008, 6, 411-423. [CrossRef]

66. Lenaz, G. Role of mitochondria in oxidative stress and ageing. Biochim. Biophys. Acta 1998, 1366, 53-67. [CrossRef] 
67. Aberg, F.; Appelkvist, E.L.; Dallner, G.; Ernster, L. Distribution and redox state of ubiquinones in rat and human tissues. Arch. Biochem. Biophys. 1992, 295, 230-234. [CrossRef]

68. Hunter, J.J.; Morgan, J.I.; Merigan, W.H.; Sliney, D.H.; Sparrow, J.R.; Williams, D.R. The susceptibility of the retina to photochemical damage from visible light. Prog. Retin. Eye Res. 2012, 31, 28-42. [CrossRef]

69. Delmelle, M. Possible implication of photooxidation reactions in retinal photo-damage. Photochem. Photobiol. 1979, 29, 713-716. [CrossRef] [PubMed]

70. Wu, J.; Seregard, S.; Algvere, P.V. Photochemical damage of the retina. Surv. Ophthalmol. 2006, 51, 461-481. [CrossRef]

71. Rozanowska, M.; Sarna, T. Light-induced damage to the retina: Role of rhodopsin chromophore revisited. Photochem. Photobiol. 2005, 81, 1305-1330. [CrossRef]

72. Farzianpour, F.; Rahimi Foroushani, A.; Shahidi Sadeghi, N.; Ansari Nosrati, S. Relationship between' patient's rights charter' and patients' satisfaction in gynecological hospitals. BMC Health Serv. Res. 2016, 16, 476. [CrossRef]

73. Contin, M.A.; Benedetto, M.M.; Quinteros-Quintana, M.L.; Guido, M.E. Light pollution: The possible consequences of excessive illumination on retina. Eye 2016, 30, 255-263. [CrossRef]

74. Sparrow, J.R.; Hicks, D.; Hamel, C.P. The retinal pigment epithelium in health and disease. Curr. Mol. Med. 2010, 10, 802-823. [CrossRef]

75. Beatty, S.; Koh, H.; Phil, M.; Henson, D.; Boulton, M. The role of oxidative stress in the pathogenesis of age-related macular degeneration. Surv. Ophthalmol. 2000, 45, 115-134. [CrossRef]

76. Schreier, S.M.; Muellner, M.K.; Steinkellner, H.; Hermann, M.; Esterbauer, H.; Exner, M.; Gmeiner, B.M.; Kapiotis, S.; Laggner, H. Hydrogen sulfide scavenges the cytotoxic lipid oxidation product 4-HNE. Neurotox. Res. 2010, 17, 249-256. [CrossRef] [PubMed]

77. Yu, L.; Kelly, U.; Ebright, J.N.; Malek, G.; Saloupis, P.; Rickman, D.W.; McKay, B.S.; Arshavsky, V.Y.; Bowes Rickman, C. Oxidative stress-induced expression and modulation of Phosphatase of Regenerating Liver-1 (PRL-1) in mammalian retina. Biochim. Biophys. Acta 2007, 1773, 1473-1482. [CrossRef] [PubMed]

78. Tanito, M.; Kwon, Y.W.; Kondo, N.; Bai, J.; Masutani, H.; Nakamura, H.; Fujii, J.; Ohira, A.; Yodoi, J. Cytoprotective effects of geranylgeranylacetone against retinal photooxidative damage. J. Neurosci. 2005, 25, 2396-2404. [CrossRef] [PubMed]

79. Sui, G.Y.; Liu, G.C.; Liu, G.Y.; Gao, Y.Y.; Deng, Y.; Wang, W.Y.; Tong, S.H.; Wang, L. Is sunlight exposure a risk factor for age-related macular degeneration? A systematic review and meta-analysis. Br. J. Ophthalmol. 2013, 97, 389-394. [CrossRef] [PubMed]

80. Ivanov, I.V.; Mappes, T.; Schaupp, P.; Lappe, C.; Wahl, S. Ultraviolet radiation oxidative stress affects eye health. J. Biophotonics 2018, 11, e201700377. [CrossRef]

81. Age-Related Eye Disease Study Research Group. A randomized, placebo-controlled, clinical trial of high-dose supplementation with vitamins $\mathrm{C}$ and $\mathrm{E}$, beta carotene, and zinc for age-related macular degeneration and vision loss: AREDS report no. 8. Arch. Ophthalmol. 2001, 119, 1417-1436. [CrossRef] [PubMed]

82. Kaarniranta, K.; Uusitalo, H.; Blasiak, J.; Felszeghy, S.; Kannan, R.; Kauppinen, A.; Salminen, A.; Sinha, D.; Ferrington, D. Mechanisms of mitochondrial dysfunction and their impact on age-related macular degeneration. Prog. Retin. Eye Res. 2020, 79, 100858. [CrossRef] [PubMed]

83. Colak, E.; Majkic-Singh, N.; Zoric, L.; Radosavljevic, A.; Kosanovic-Jakovic, N. The impact of inflammation to the antioxidant defense parameters in AMD patients. Aging Clin. Exp. Res. 2012, 24, 588-594. [CrossRef] [PubMed]

84. Kauppinen, A.; Niskanen, H.; Suuronen, T.; Kinnunen, K.; Salminen, A.; Kaarniranta, K. Oxidative stress activates NLRP3 inflammasomes in ARPE-19 cells-implications for age-related macular degeneration (AMD). Immunol. Lett. 2012, 147, 29-33. [CrossRef] [PubMed]

85. Bian, Q.; Gao, S.; Zhou, J.; Qin, J.; Taylor, A.; Johnson, E.J.; Tang, G.; Sparrow, J.R.; Gierhart, D.; Shang, F. Lutein and zeaxanthin supplementation reduces photooxidative damage and modulates the expression of inflammation-related genes in retinal pigment epithelial cells. Free Radic. Biol. Med. 2012, 53, 1298-1307. [CrossRef] [PubMed]

86. Wenzel, A.; Grimm, C.; Marti, A.; Kueng-Hitz, N.; Hafezi, F.; Niemeyer, G.; Reme, C.E. c-fos controls the "private pathway" of light-induced apoptosis of retinal photoreceptors. J. Neurosci. 2000, 20, 81-88. [CrossRef]

87. Roehlecke, C.; Schumann, U.; Ader, M.; Brunssen, C.; Bramke, S.; Morawietz, H.; Funk, R.H. Stress reaction in outer segments of photoreceptors after blue light irradiation. PLOS ONE 2013, 8, e71570. [CrossRef]

88. Wenzel, A.; Grimm, C.; Samardzija, M.; Reme, C.E. The genetic modifier Rpe65Leu(450): Effect on light damage susceptibility in c-Fos-deficient mice. Investig. Ophthalmol. Vis. Sci. 2003, 44, 2798-2802. [CrossRef]

89. Nucci, C.; Tartaglione, R.; Cerulli, A.; Mancino, R.; Spano, A.; Cavaliere, F.; Rombola, L.; Bagetta, G.; Corasaniti, M.T.; Morrone, L.A. Retinal damage caused by high intraocular pressure-induced transient ischemia is prevented by coenzyme Q10 in rat. Int. Rev. Neurobiol. 2007, 82, 397-406. [CrossRef]

90. Russo, R.; Cavaliere, F.; Rombola, L.; Gliozzi, M.; Cerulli, A.; Nucci, C.; Fazzi, E.; Bagetta, G.; Corasaniti, M.T.; Morrone, L.A. Rational basis for the development of coenzyme Q10 as a neurotherapeutic agent for retinal protection. Prog. Brain Res. 2008, 173, 575-582. [CrossRef]

91. Nucci, C.; Russo, R.; Martucci, A.; Giannini, C.; Garaci, F.; Floris, R.; Bagetta, G.; Morrone, L.A. New strategies for neuroprotection in glaucoma, a disease that affects the central nervous system. Eur. J. Pharmacol. 2016, 787, 119-126. [CrossRef]

92. Mancino, R.; Cesareo, M.; Martucci, A.; Di Carlo, E.; Ciuffoletti, E.; Giannini, C.; Morrone, L.A.; Nucci, C.; Garaci, F. Neurodegenerative Process Linking the Eye and the Brain. Curr. Med. Chem. 2019, 26, 3754-3763. [CrossRef] 
93. Schmidl, D.; Garhofer, G.; Schmetterer, L. The complex interaction between ocular perfusion pressure and ocular blood flowrelevance for glaucoma. Exp. Eye Res. 2011, 93, 141-155. [CrossRef]

94. Kowluru, R.A.; Tang, J.; Kern, T.S. Abnormalities of retinal metabolism in diabetes and experimental galactosemia. VII. Effect of long-term administration of antioxidants on the development of retinopathy. Diabetes 2001, 50, 1938-1942. [CrossRef] [PubMed]

95. Haskins, K.; Bradley, B.; Powers, K.; Fadok, V.; Flores, S.; Ling, X.; Pugazhenthi, S.; Reusch, J.; Kench, J. Oxidative stress in type 1 diabetes. Ann. N. Y. Acad. Sci. 2003, 1005, 43-54. [CrossRef]

96. Kanwar, M.; Chan, P.S.; Kern, T.S.; Kowluru, R.A. Oxidative damage in the retinal mitochondria of diabetic mice: Possible protection by superoxide dismutase. Investig. Ophthalmol. Vis. Sci. 2007, 48, 3805-3811. [CrossRef] [PubMed]

97. Narayanan, S.P.; Rojas, M.; Suwanpradid, J.; Toque, H.A.; Caldwell, R.W.; Caldwell, R.B. Arginase in retinopathy. Prog. Retin. Eye Res. 2013, 36, 260-280. [CrossRef] [PubMed]

98. Roy, S.; Kern, T.S.; Song, B.; Stuebe, C. Mechanistic insights into pathological changes in the diabetic retina: Implications for targeting diabetic retinopathy. Am. J. Pathol. 2017, 187, 9-19. [CrossRef] [PubMed]

99. Beatty, S.; Murray, I.J.; Henson, D.B.; Carden, D.; Koh, H.; Boulton, M.E. Macular pigment and risk for age-related macular degeneration in subjects from a Northern European population. Investig. Ophthalmol. Vis. Sci. 2001, 42, 439-446.

100. Campochiaro, P.A.; Mir, T.A. The mechanism of cone cell death in Retinitis Pigmentosa. Prog. Retin. Eye Res. 2018, 62, 24-37. [CrossRef] [PubMed]

101. AnandBabu, K.; Bharathidevi, S.R.; Sripriya, S.; Sen, P.; Prakash, V.J.; Bindu, A.; Viswanathan, N.; Angayarkanni, N. Serum Paraoxonase activity in relation to lipid profile in Age-related Macular Degeneration patients. Exp. Eye Res. 2016, 152, 100-112. [CrossRef] [PubMed]

102. Olson, K.R. Are Reactive Sulfur Species the New Reactive Oxygen Species? Antioxid. Redox Signal. 2020, 33, 1125-1142. [CrossRef] [PubMed]

103. Kimura, H.; Nagai, Y.; Umemura, K.; Kimura, Y. Physiological roles of hydrogen sulfide: Synaptic modulation, neuroprotection, and smooth muscle relaxation. Antioxid. Redox Signal. 2005, 7, 795-803. [CrossRef] [PubMed]

104. Kimura, Y.; Goto, Y.; Kimura, H. Hydrogen sulfide increases glutathione production and suppresses oxidative stress in mitochondria. Antioxid. Redox Signal. 2010, 12,1-13. [CrossRef] [PubMed]

105. Roh, Y.J.; Moon, C.; Kim, S.Y.; Park, M.H.; Bae, Y.C.; Chun, M.H.; Moon, J.I. Glutathione depletion induces differential apoptosis in cells of mouse retina, in vivo. Neurosci. Lett. 2007, 417, 266-270. [CrossRef] [PubMed]

106. Bhattacharyya, S.; Saha, S.; Giri, K.; Lanza, I.R.; Nair, K.S.; Jennings, N.B.; Rodriguez-Aguayo, C.; Lopez-Berestein, G.; Basal, E.; Weaver, A.L.; et al. Cystathionine beta-synthase (CBS) contributes to advanced ovarian cancer progression and drug resistance. PLoS ONE 2013, 8, e79167. [CrossRef]

107. Ansari, R.; Mahta, A.; Mallack, E.; Luo, J.J. Hyperhomocysteinemia and neurologic disorders: A review. J. Clin. Neurol. 2014, 10, 281-288. [CrossRef]

108. Markand, S.; Tawfik, A.; Ha, Y.; Gnana-Prakasam, J.; Sonne, S.; Ganapathy, V.; Sen, N.; Xian, M.; Smith, S.B. Cystathionine beta synthase expression in mouse retina. Curr. Eye Res. 2013, 38, 597-604. [CrossRef]

109. George, A.K.; Singh, M.; Homme, R.P.; Majumder, A.; Sandhu, H.S.; Tyagi, S.C. A hypothesis for treating inflammation and oxidative stress with hydrogen sulfide during age-related macular degeneration. Int. J. Ophthalmol. 2018, 11, 881-887. [CrossRef]

110. Sakamoto, K.; Suzuki, Y.; Kurauchi, Y.; Mori, A.; Nakahara, T.; Ishii, K. Hydrogen sulfide attenuates NMDA-induced neuronal injury via its anti-oxidative activity in the rat retina. Exp. Eye Res. 2014, 120, 90-96. [CrossRef]

111. Huang, S.; Huang, P.; Lin, Z.; Liu, X.; Xu, X.; Guo, L.; Shen, X.; Li, C.; Zhong, Y. Hydrogen sulfide supplement attenuates the apoptosis of retinal ganglion cells in experimental glaucoma. Exp. Eye Res. 2018, 168, 33-48. [CrossRef]

112. Du, J.; Jin, H.; Yang, L. Role of Hydrogen Sulfide in Retinal Diseases. Front. Pharmacol. 2017, 8, 588. [CrossRef]

113. Sone, K.; Mori, A.; Sakamoto, K.; Nakahara, T. GYY4137, an Extended-Release Hydrogen Sulfide Donor, Reduces NMDA-Induced Neuronal Injury in the Murine Retina. Biol. Pharm. Bull. 2018, 41, 657-660. [CrossRef]

114. Minamishima, S.; Bougaki, M.; Sips, P.Y.; Yu, J.D.; Minamishima, Y.A.; Elrod, J.W.; Lefer, D.J.; Bloch, K.D.; Ichinose, F. Hydrogen sulfide improves survival after cardiac arrest and cardiopulmonary resuscitation via a nitric oxide synthase 3-dependent mechanism in mice. Circulation 2009, 120, 888-896. [CrossRef]

115. Kohl, J.B.; Mellis, A.T.; Schwarz, G. Homeostatic impact of sulfite and hydrogen sulfide on cysteine catabolism. Br. J. Pharmacol. 2019, 176, 554-570. [CrossRef] [PubMed]

116. Martin, C.; Houitte, D.; Guillermier, M.; Petit, F.; Bonvento, G.; Gurden, H. Alteration of sensory-evoked metabolic and oscillatory activities in the olfactory bulb of GLAST-deficient mice. Front. Neural Circuits 2012, 6, 1. [CrossRef] [PubMed]

117. Albini, T.A.; Wang, R.C.; Reiser, B.; Zamir, E.; Wu, G.S.; Rao, N.A. Microglial stability and repopulation in the retina. Br. J. Ophthalmol. 2005, 89, 901-903. [CrossRef] [PubMed]

118. Ajami, B.; Bennett, J.L.; Krieger, C.; Tetzlaff, W.; Rossi, F.M. Local self-renewal can sustain CNS microglia maintenance and function throughout adult life. Nat. Neurosci. 2007, 10, 1538-1543. [CrossRef]

119. Minami, M.; Kuraishi, Y.; Satoh, M. Effects of kainic acid on messenger RNA levels of IL-1 beta, IL-6, TNF alpha and LIF in the rat brain. Biochem. Biophys. Res. Commun. 1991, 176, 593-598. [CrossRef]

120. Bannai, S.; Kitamura, E. Transport interaction of L-cystine and L-glutamate in human diploid fibroblasts in culture. J. Biol. Chem. 1980, 255, 2372-2376. [CrossRef] 
121. Huang, S.; Huang, P.; Yu, H.; Lin, Z.; Liu, X.; Shen, X.; Guo, L.; Zhong, Y. Extracellular Signal-Regulated Kinase $1 / 2$ Pathway Is Insufficiently Involved in the Neuroprotective Effect by Hydrogen Sulfide Supplement in Experimental Glaucoma. Investig. Ophthalmol. Vis. Sci. 2019, 60, 4346-4359. [CrossRef]

122. Yamamoto, K.; Maruyama, K.; Himori, N.; Omodaka, K.; Yokoyama, Y.; Shiga, Y.; Morin, R.; Nakazawa, T. The novel Rho kinase (ROCK) inhibitor K-115: A new candidate drug for neuroprotective treatment in glaucoma. Investig. Ophthalmol. Vis. Sci. 2014, 55, 7126-7136. [CrossRef]

123. Si, Y.F.; Wang, J.; Guan, J.; Zhou, L.; Sheng, Y.; Zhao, J. Treatment with hydrogen sulfide alleviates streptozotocin-induced diabetic retinopathy in rats. Br. J. Pharmacol. 2013, 169, 619-631. [CrossRef] [PubMed]

124. Da Costa, C.A.; Masliah, E.; Checler, F. Beta-synuclein displays an antiapoptotic p53-dependent phenotype and protects neurons from 6-hydroxydopamine-induced caspase 3 activation: Cross-talk with alpha-synuclein and implication for Parkinson's disease. J. Biol. Chem. 2003, 278, 37330-37335. [CrossRef]

125. Surguchov, A. Intracellular Dynamics of Synucleins: “Here, There and Everywhere". Int. Rev. Cell. Mol. Biol. 2015, 320, 103-169. [CrossRef] [PubMed]

126. Beraud, D.; Twomey, M.; Bloom, B.; Mittereder, A.; Ton, V.; Neitzke, K.; Chasovskikh, S.; Mhyre, T.R.; Maguire-Zeiss, K.A. Alpha-Synuclein Alters Toll-Like Receptor Expression. Front. Neurosci. 2011, 5, 80. [CrossRef]

127. Surguchov, A.; McMahan, B.; Masliah, E.; Surgucheva, I. Synucleins in ocular tissues. J. Neurosci. Res. 2001, 65, 68-77. [CrossRef]

128. Hadrian, K.; Melkonyan, H.; Schlatt, S.; Wistuba, J.; Wasmuth, S.; Heiligenhaus, A.; Thanos, S.; Bohm, M.R.R. Age-related distribution and potential role of SNCB in topographically different retinal areas of the common marmoset Callithrix jacchus, including the macula. Exp. Eye Res. 2019, 185, 107676. [CrossRef] [PubMed]

129. Brockhaus, K.; Bohm, M.R.R.; Melkonyan, H.; Thanos, S. Age-related Beta-synuclein Alters the p53/Mdm2 Pathway and Induces the Apoptosis of Brain Microvascular Endothelial Cells In Vitro. Cell. Transplant. 2018, 27, 796-813. [CrossRef] [PubMed]

130. Tenreiro, S.; Rosado-Ramos, R.; Gerhardt, E.; Favretto, F.; Magalhaes, F.; Popova, B.; Becker, S.; Zweckstetter, M.; Braus, G.H.; Outeiro, T.F. Yeast reveals similar molecular mechanisms underlying alpha- and beta-synuclein toxicity. Hum. Mol. Genet. 2016, 25, 275-290. [CrossRef]

131. Tabassum, R.; Jeong, N.Y.; Jung, J. Therapeutic importance of hydrogen sulfide in age-associated neurodegenerative diseases. Neural Regen. Res. 2020, 15, 653-662. [CrossRef]

132. Kumar, M.; Sandhir, R. Hydrogen sulfide suppresses homocysteine-induced glial activation and inflammatory response. Nitric Oxide 2019, 90, 15-28. [CrossRef]

133. Longhena, F.; Faustini, G.; Brembati, V.; Pizzi, M.; Bellucci, A. The good and bad of therapeutic strategies that directly target alpha-synuclein. IUBMB Life 2020, 72, 590-600. [CrossRef]

134. Liu, H.; Mercieca, K.; Anders, F.; Prokosch, V. Hydrogen Sulfide and beta-Synuclein Are Involved and Interlinked in the Aging Glaucomatous Retina. J. Ophthalmol. 2020, 2020, 8642135. [CrossRef]

135. Liu, H.; Perumal, N.; Manicam, C.; Mercieca, K.; Prokosch, V. Proteomics Reveals the Potential Protective Mechanism of Hydrogen Sulfide on Retinal Ganglion Cells in an Ischemia/Reperfusion Injury Animal Model. Pharmaceuticals 2020, 13, 213. [CrossRef]

136. Friedman, P.A.; Zeidel, M.L. Victory at C. Nat. Med. 1999, 5, 620-621. [CrossRef]

137. Hosoya, K.; Tomi, M. Advances in the cell biology of transport via the inner blood-retinal barrier: Establishment of cell lines and transport functions. Biol. Pharm. Bull. 2005, 28, 1-8. [CrossRef] [PubMed]

138. Hosoya, K.; Minamizono, A.; Katayama, K.; Terasaki, T.; Tomi, M. Vitamin C transport in oxidized form across the rat blood-retinal barrier. Investig. Ophthalmol. Vis. Sci. 2004, 45, 1232-1239. [CrossRef] [PubMed]

139. Del Amo, E.M.; Rimpela, A.K.; Heikkinen, E.; Kari, O.K.; Ramsay, E.; Lajunen, T.; Schmitt, M.; Pelkonen, L.; Bhattacharya, M.; Richardson, D.; et al. Pharmacokinetic aspects of retinal drug delivery. Prog. Retin. Eye Res. 2017, 57, 134-185. [CrossRef] [PubMed]

140. Juuti-Uusitalo, K.; Vaajasaari, H.; Ryhanen, T.; Narkilahti, S.; Suuronen, R.; Mannermaa, E.; Kaarniranta, K.; Skottman, H. Efflux protein expression in human stem cell-derived retinal pigment epithelial cells. PLoS ONE 2012, 7, e30089. [CrossRef]

141. Mannermaa, E.; Vellonen, K.S.; Ryhanen, T.; Kokkonen, K.; Ranta, V.P.; Kaarniranta, K.; Urtti, A. Efflux protein expression in human retinal pigment epithelium cell lines. Pharm. Res. 2009, 26, 1785-1791. [CrossRef]

142. Nevala, H.; Ylikomi, T.; Tahti, H. Evaluation of the selected barrier properties of retinal pigment epithelial cell line ARPE-19 for an in-vitro blood-brain barrier model. Hum. Exp. Toxicol. 2008, 27, 741-749. [CrossRef] [PubMed]

143. Sreekumar, P.G.; Spee, C.; Ryan, S.J.; Cole, S.P.; Kannan, R.; Hinton, D.R. Mechanism of RPE cell death in alpha-crystallin deficient mice: A novel and critical role for MRP1-mediated GSH efflux. PLoS ONE 2012, 7, e33420. [CrossRef]

144. Ryhanen, T.; Mannermaa, E.; Oksala, N.; Viiri, J.; Paimela, T.; Salminen, A.; Atalay, M.; Kaarniranta, K. Radicicol but not geldanamycin evokes oxidative stress response and efflux protein inhibition in ARPE-19 human retinal pigment epithelial cells. Eur. J. Pharmacol. 2008, 584, 229-236. [CrossRef]

145. Vadlapatla, R.K.; Vadlapudi, A.D.; Ponnaluri, V.K.; Pal, D.; Mukherji, M.; Mitra, A.K. Molecular expression and functional activity of efflux and influx transporters in hypoxia induced retinal pigment epithelial cells. Int. J. Pharm. 2013, 454, 444-452. [CrossRef]

146. Zhang, Y.; Li, C.; Sun, X.; Kuang, X.; Ruan, X. High glucose decreases expression and activity of p-glycoprotein in cultured human retinal pigment epithelium possibly through iNOS induction. PLoS ONE 2012, 7, e31631. [CrossRef] [PubMed] 
147. Zhang, Y.; Lu, M.; Sun, X.; Li, C.; Kuang, X.; Ruan, X. Expression and activity of p-glycoprotein elevated by dexamethasone in cultured retinal pigment epithelium involve glucocorticoid receptor and pregnane $\mathrm{X}$ receptor. Investig. Ophthalmol. Vis. Sci. 2012, 53, 3508-3515. [CrossRef] [PubMed]

148. Bianchi, J.; Rose, R.C. Dehydroascorbic acid and cell membranes: Possible disruptive effects. Toxicology 1986, 40, 75-82. [CrossRef]

149. Hosoya, K.; Nakamura, G.; Akanuma, S.; Tomi, M.; Tachikawa, M. Dehydroascorbic acid uptake and intracellular ascorbic acid accumulation in cultured Muller glial cells (TR-MUL). Neurochem. Int. 2008, 52, 1351-1357. [CrossRef] [PubMed]

150. Garcia-Krauss, A.; Ferrada, L.; Astuya, A.; Salazar, K.; Cisternas, P.; Martinez, F.; Ramirez, E.; Nualart, F. Dehydroascorbic Acid Promotes Cell Death in Neurons Under Oxidative Stress: A Protective Role for Astrocytes. Mol. Neurobiol. 2016, 53, 5847-5863. [CrossRef]

151. Gutteridge, J.M.; Halliwell, B. Free radicals and antioxidants in the year 2000. A historical look to the future. Ann. N. Y. Acad. Sci. 2000, 899, 136-147. [CrossRef]

152. Gozzelino, R.; Arosio, P. Iron Homeostasis in Health and Disease. Int. J. Mol. Sci 2016, 17, 130. [CrossRef]

153. Lillig, C.H.; Berndt, C.; Holmgren, A. Glutaredoxin systems. Biochim. Biophys. Acta 2008, 1780, 1304-1317. [CrossRef]

154. Qi, W.; Li, J.; Chain, C.Y.; Pasquevich, G.A.; Pasquevich, A.F.; Cowan, J.A. Glutathione complexed Fe-S centers. J. Am. Chem. Soc. 2012, 134, 10745-10748. [CrossRef]

155. Iwema, T.; Picciocchi, A.; Traore, D.A.; Ferrer, J.L.; Chauvat, F.; Jacquamet, L. Structural basis for delivery of the intact [Fe2S2] cluster by monothiol glutaredoxin. Biochemistry 2009, 48, 6041-6043. [CrossRef] [PubMed]

156. Sen, S.; Rao, B.; Wachnowsky, C.; Cowan, J.A. Cluster exchange reactivity of [2Fe-2S] cluster-bridged complexes of BOLA3 with monothiol glutaredoxins. Metallomics 2018, 10, 1282-1290. [CrossRef] [PubMed]

157. Xia, H.; Li, B.; Zhang, Z.; Wang, Q.; Qiao, T.; Li, K. Human glutaredoxin 3 can bind and effectively transfer [4Fe-4S] cluster to apo-iron regulatory protein 1. Biochem. Biophys. Res. Commun. 2015, 465, 620-624. [CrossRef] [PubMed]

158. Li, H.; Mapolelo, D.T.; Dingra, N.N.; Naik, S.G.; Lees, N.S.; Hoffman, B.M.; Riggs-Gelasco, P.J.; Huynh, B.H.; Johnson, M.K.; Outten, C.E. The yeast iron regulatory proteins Grx3/4 and Fra2 form heterodimeric complexes containing a [2Fe-2S] cluster with cysteinyl and histidyl ligation. Biochemistry 2009, 48, 9569-9581. [CrossRef] [PubMed]

159. Alavi, F.S.; Gheidi, M.; Zahedi, M.; Safari, N.; Ryde, U. A novel mechanism of heme degradation to biliverdin studied by QM/MM and QM calculations. Dalton Trans. 2018, 47, 8283-8291. [CrossRef]

160. Durgin, B.G.; Hahn, S.A.; Schmidt, H.M.; Miller, M.P.; Hafeez, N.; Mathar, I.; Freitag, D.; Sandner, P.; Straub, A.C. Loss of smooth muscle CYB5R3 amplifies angiotensin II-induced hypertension by increasing sGC heme oxidation. JCI Insight 2019, 4, e129183. [CrossRef] 